\title{
Cytocidal effects of arenobufagin and hellebrigenin, two active bufadienolide compounds, against human glioblastoma cell line $\mathrm{U}-87$
}

\author{
LINGYU HAN $^{1,2^{*}}$, BO YUAN $^{1 *}$, RYOTA SHIMADA $^{1}$, HIDEKI HAYASHI $^{1}$, NAN SI $^{2}$, \\ HAI-YU ZHAO ${ }^{2}$, BAOLIN BIAN ${ }^{2}$ and NORIO TAKAGI ${ }^{1}$ \\ ${ }^{1}$ Department of Applied Biochemistry, School of Pharmacy, Tokyo University of Pharmacy \& Life Sciences, \\ Tokyo 192-0392, Japan; ${ }^{2}$ Institute of Chinese Materia Medica, \\ China Academy of Chinese Medical Sciences, Beijing 100700, P.R. China
}

Received March 8, 2018; Accepted July 18, 2018

DOI: 10.3892/ijo.2018.4567

\begin{abstract}
Glioblastoma is the most common and lethal intracranial tumor type, characterized by high angiogenic and infiltrative capacities. To provide a novel insight into therapeutic strategies against glioblastoma, the cytotoxicity of arenobufagin and hellebrigenin was investigated in the human glioblastoma cell line, U-87. Similar dose-dependent cytotoxicity was observed in the cells, whereas no detectable toxicity was confirmed in mouse primary astrocytes. Treatment with each drug downregulated the expression levels of Cdc25C, Cyclin B1 and survivin, which occurred in parallel with $\mathrm{G}_{2} / \mathrm{M}$ phase arrest. Necrotic-like cell death was only observed in the cells treated with a relatively high concentration $(>100 \mathrm{ng} / \mathrm{ml})$. These results indicate that the two drugs exhibited distinct cytotoxicity against cancerous glial cells with high potency and selectivity, suggesting that growth inhibition associated with $\mathrm{G}_{2} / \mathrm{M}$ phase arrest and/or necrosis were attributed to their toxicities. Activation of the p38 mitogen activated protein kinase (MAPK) signaling pathway was also observed in treated cells. Notably, a specific inhibitor of p38 MAPK, SB203580, itself caused a significant decrease in cell viability, and further enhanced the cytotoxicity of the two drugs, suggesting an important pro-survival role for p38 MAPK. Given that p38 MAPK serves an essential role in promoting glioblastoma cell survival, developing a novel combination regimen of arenobufagin/hellebrigenin plus a p38 MAPK inhibitor may improve the efficacy of the two
\end{abstract}

Correspondence to: $\operatorname{Dr}$ Bo Yuan, Department of Applied Biochemistry, School of Pharmacy, Tokyo University of Pharmacy \& Life Sciences, 1432-1 Horinouchi, Hachioji, Tokyo 192-0392, Japan E-mail: yuanbo@toyaku.ac.jp

*Contributed equally

Key words: arenobufagin, hellebrigenin, bufadienolide compounds, glioblastoma, G2/M cell cycle arrest, p38 mitogen activated protein kinase drugs, and may provide more therapeutic benefits to patients with glioblastoma. The qualitative assessment demonstrated the existence of arenobufagin in the cerebrospinal fluid of arenobufagin-treated rats, supporting its clinical application.

\section{Introduction}

Glioblastoma, classified as a grade IV astrocytoma according to the World Health Organization prognostic system, is the most common and lethal type of intracranial tumor, characterized by high angiogenic and infiltrative capacities $(1,2)$. The current standard treatment for glioblastoma consists of maximal surgical resection, radiotherapy, and concomitant and adjuvant chemotherapy with temozolomide $(1,3)$. Despite advances in the understanding of the molecular pathogenesis of glioblastoma, diagnosis, and more promising and tailored therapeutic approaches, the median survival time of patients with glioblastoma remains $<1$ year $(4,5)$. The requirement for novel therapeutic strategies remains paramount given the sustained development of drug resistance and tumor recurrence.

Bufadienolides are the major effective constituents of cinobufacini (also known as Huachansu), a well-known Chinese medicine that comes from the dried skin of Bufo bufo gargarizans Cantor, and cinobufacini has been used to treat patients with various types of cancer, including hepatoma, gallbladder carcinoma and lung cancer in China (6-8). The authors of the present study recently demonstrated that active bufadienolide compounds, including gamabufotalin and arenobufagin, exhibit selective cytocidal effects against intractable cancer cells, including in glioblastoma, but minimal effects on normal peripheral blood mononuclear cells (PBMCs) prepared from healthy volunteers (9). Notably, it was demonstrated that nearly non-toxic gamabufotalin concentrations on PBMCs efficiently downregulated the percentages of $\mathrm{CD}^{+}{ }^{+} \mathrm{CD} 25^{+} \mathrm{Fop} 3^{+}$regulatory $\mathrm{T}$ (Treg) cells (9), which have been considered to serve an important role in limiting antitumor immune response in the body and promoting immunological ignorance of cancer cells (10-12). These results suggest that bufadienolides, including gamabufotalin and arenobufagin, may provide a therapeutic benefit to patients with glioblastoma via their 
cytocidal effects against tumor cells and antitumor immunitypromoting characteristics. Despite the selective cytocidal effects of bufadienolides against glioblastoma and their possibility for further clinical applications, the detailed molecular mechanisms of action of these active bufadienolides in glioblastoma cells remain unexplored.

Cell cycle arrest, necrosis and apoptosis are considered the major mechanisms underlying the cytocidal effects of the majority of chemotherapeutic drugs (13-15). A number of previous studies have demonstrated that active bufadienolides, including bufalin, arenobufagin and hellebrigenin, induce cytotoxicity associated with cell cycle arrest (16-18). They have also been implicated in the inhibition of the phosphatidylinositol 3-kinase (PI3K)/AKT serine/threonine kinase (Akt) signaling pathway, and downregulation of essential regulators of the cell cycle transition, such as Cdc25C and Cyclin B1, in human hepatocellular carcinoma cells (16-18). Survivin, a well-known cancer-associated protein that is highly expressed in the majority of human tumor cells, has been associated with an increase in the malignant potential of human glioma, and is considered to serve an important role in mediating radiation resistance in primary glioblastoma cells (19). In addition, members of the mitogen-activated protein kinase (MAPK) family are involved in cell cycle arrest, cell death signaling and the regulation of growth. The MAPKs include p38 kinase, c-Jun NH2-terminal protein kinase (JNK) and extracellular signal-regulated kinase (Erk) (20). Similar to Akt, Erk is usually referred to as a survival mediator involved in cytoprotection $(21,22)$. Although p38 MAPK and JNK are generally considered to be required for the induction of cell death by diverse stimuli $(21,23,24)$, a novel prosurvival role for p38 MAPK has been reported in human cancer cells, including in glioblastoma cells (25-27). However, whether and how these molecules contribute to the potential cytotoxic effects induced by active bufadienolides against glioblastoma cells, and the association between these molecules and cellular responses, including cell cycle arrest, remain to be elucidated.

In the current study, the cytotoxicity of two active bufadienolide compounds, arenobufagin and hellebrigenin, was investigated in the human glioblastoma cell line U-87 by focusing on proliferation inhibition associated with cell cycle arrest, necrosis as well as apoptosis, in order to provide novel insight into therapeutic approaches against glioblastoma. Primary mouse astrocytes were also used to evaluate whether the two drugs exhibited cytotoxic selectivity for cancer cells, rather than normal cells. Key regulatory molecules involved in the cell cycle and cell death were investigated to further elucidate the cytotoxic mechanisms. Considering the controversial role of p38 MAPK in cell death/survival in human cancer cells, the details of whether and how p38 MAPK is implicated in active bufadienolides-mediated cytocidal effects in U-87 cells were also investigated using its specific inhibitor, SB203580.

\section{Materials and methods}

Materials. Arenobufagin was purchased from Baoji Herbest Bio-Tech Co., Ltd. (Baoji, China). XTT, propidium iodide (PI), proteinase K, Hoechst 33258 and ribonuclease A (RNaseA) were purchased from Merck KGaA (Darmstadt, Germany). Dulbecco's modified Eagle's medium (DMEM), phenazine methosulfate, agarose $\mathrm{X}$ and $25 \%$ glutaraldehyde solution were purchased from Wako Pure Chemical Industries, Ltd. (Osaka, Japan). Crystal violet (C.I. 42555) Certistain ${ }^{\circledR}$ was purchased from Merck KGaA. SB203580, a specific inhibitor of p38 MAPK, and its negative control SB202474 were purchased from Merck KGaA. Fetal bovine serum (FBS) was obtained from Nichirei Biosciences, Inc. (Tokyo, Japan). High performance liquid chromatography (HPLC)-grade acetonitrile and methanol were purchased from Thermo Fisher Scientific, Inc. (Waltham, MA, USA). Mass spectrometry (MS)-grade formic acid was obtained from ROE Scientific, Inc. (Newark, DE, USA).

Isolation and identification of hellebrigenin from the dried skin of Bufo bufo gargarizans Cantor. Dried skin of Bufo bufo gargarizans Cantor was purchased from Anhui Jinchan Biochemistry Co., Ltd. (Huaibei, China), and further identified by Professor Hongjie Wang (Institute of Chinese Materia Medica, China Academy of Chinese Medical Sciences, Beijing, China). The dried toad skin (10 kg) was cut into pieces, and then extracted under reflux with $95 \%$ ethanol into 20 liters. The extracting solution was dried with rotary evaporation at $45^{\circ} \mathrm{C}$ under reduced pressure (vacuum drying) to yield $\sim 150 \mathrm{~g}$ residue. Following separation through a silica gel (2,000 g; 160-200 mesh; Qingdao Haiyang Chemical Co., Ltd., Qingdao, China) column chromatography with chloroformmethanol solution (50:1-1:1) with gradient elution, a total of eight fractions were obtained (Fr. 1-8). Fr. 4 (8 g) was further separated by C18 (320 ml; SP-120-50-ODS-RPS; DAISO Co., Ltd., Osaka, Japan) column chromatography using $30 \%$ (500 ml, Fr. 4.1-4.5), $40 \%$ (500 ml, Fr. 4.6-4.10), 50\% (500 ml, Fr. 4.11-4.15) and 60\% (400 ml, Fr. 4.16-4.19) methanol. Hellebrigenin was purified from Fr. 4.10-4.16 by preparative HPLC. It was obtained as a white powder with molecular formula of $\mathrm{C}_{24} \mathrm{H}_{32} \mathrm{O}_{6}$ based on high-resolution electrospray ionization MS (HR-ESI-MS). The compound was identified as hellebrigenin with $>96 \%$ purity according to previously reported values (28).

Cell culture and treatment. U-87, a human glioblastoma cell line, was obtained from the American Type Culture Collection (Manassas, VA, USA) and cultured in DMEM supplemented with $10 \%$ heat-inactivated FBS, $100 \mathrm{U} / \mathrm{ml}$ of penicillin and $100 \mu \mathrm{g} / \mathrm{ml}$ of streptomycin (both from Wako Pure Chemical Industries, Ltd.) in a humidified atmosphere with $5 \% \mathrm{CO}_{2}$ at $37^{\circ} \mathrm{C}$. Primary mouse glial cells were prepared according to a method previously reported with modifications (29). Briefly, the cerebral cortex of 4-5 newborn C57BL/6J mice [2-4 days old (sex unconfirmed), body weight $2-3 \mathrm{~g}$, housed at $23 \pm 1^{\circ} \mathrm{C}$ in a room with a constant humidity of $55 \pm 5 \%$ and a regular 12-h light/12-h dark cycle together with dams] was removed and digested by trituration in PBS (Wako Pure Chemical Industries, Inc.) containing $0.25 \%$ trypsin. Dissociated glial cells were cultured in $75 \mathrm{~cm}^{2}$ flasks (BD Biosciences, Franklin Lakes, NJ, USA) in DMEM containing 10\% FBS in a humidified atmosphere with $5 \% \mathrm{CO}_{2}$ at $37^{\circ} \mathrm{C}$.

After 2 days of cultivation, the medium was changed to remove unattached cells. Glial cells were allowed to form a confluent monolayer for 7-9 days and harvested from the flask by treatment with $0.125 \%$ trypsin. Subsequently, cells were 
seeded at a density of $5 \times 10^{5}$ cells $/ \mathrm{ml}$ in $96-$ well plates and allowed to grow to $\sim 80 \%$ confluency. The glial cell preparation was highly enriched in astrocytes ( $>90 \%)$ according our previous report (29). The U-87 and primary glial cells were treated with SB203580, a specific inhibitor of p38 MAPK, and its negative control SB202474 at various concentrations $(1,5$ or $10 \mu \mathrm{M}$ ) for $30 \mathrm{~min}$ prior to treatment with arenobufagin and hellebrigenin $[20 \mathrm{ng} / \mathrm{ml}$, almost equal to their half maximal inhibitory concentration $\left(\mathrm{IC}_{50}\right)$ values at $48 \mathrm{~h}$ ], in the presence or absence of these reagents. The present study was approved by the Committee of Animal Care and Welfare of Tokyo University of Pharmacy and Life Sciences (Tokyo, Japan; registration no. P17-60).

Qualitative assessment of arenobufagin and hellebrigenin in the cerebrospinal fluid of rats receiving a single oral dose of arenobufagin or hellebrigenin. As mice are too small to successfully collect clear cerebrospinal fluid without blood contamination, and there is no clear difference in the structure and function of the blood-brain barrier (BBB) in rats and mice, rats were used instead of mice for the qualitative assessment. Nine male Sprague Dawley rats (220-240 g) were purchased from Shanghai Shibei Biotechnology Co., Ltd. (Shanghai, China), and housed at $23 \pm 1^{\circ} \mathrm{C}$ in a room with a constant humidity of $55 \pm 5 \%$ and a regular $12 / 12$-h light/dark cycle for one week prior to experimentation. Throughout the experiment, the rats had free access to food and water. After an overnight fasting with water not limited, all animals were randomly divided into three groups $(n=3)$ and administered the following treatments: Vehicle control (saline), arenobufagin $(50 \mathrm{mg} / \mathrm{kg})$ and hellebrigenin $(50 \mathrm{mg} / \mathrm{kg})$. All animals received a single oral dose of $50 \mathrm{mg}$ arenobufagin/hellebrigenin or the same volume of saline $/ \mathrm{kg}$ of body weight. At $30 \mathrm{~min}$ after the oral administration, cerebrospinal fluids were collected according to the method previously described with slight modifications (30). Briefly, the fur on the head and neck regions of rats were carefully removed, and animals were placed in an induction chamber and anesthetized. Following disinfection with ethanol, an 2 -cm skin incision was made along the midline. The spinous process and lamina were clamped with hemostatic forceps in order to make the arachnoid membrane more visible. Then, the cerebrospinal fluid was carefully extracted from the subarachnoid space using a 1 -ml syringe with a $23 \mathrm{G}$ needle without blood contamination. Following centrifugation at $9,730 \times \mathrm{g}$ for $15 \mathrm{~min}$ at $4^{\circ} \mathrm{C}$, the cerebrospinal fluid supernatants were collected and stored at $-20^{\circ} \mathrm{C}$ for later analysis.

The analysis of cerebrospinal fluids was performed using the ultimate 3000 hyperbaric LC system coupled with a Velos Pro LTQ Orbitrap Mass Spectrometer via an ESI interface from Thermo Fisher Scientific, Inc. Eclipse XDB-C18 (4.6x150 mm, $3.5 \mu \mathrm{m}$; Agilent Technologies, Inc., Santa Clara, CA, USA) was used as the separation column in the ultra HPLC. The mobile phase consisted of $0.1 \%$ formic acid in water (solvent A) and acetonitrile (solvent B), with the gradient elution as follows: $0-5 \mathrm{~min}, 20-40 \% \mathrm{~B}$; $5-20 \mathrm{~min}, 40-50 \% \mathrm{~B}$; 20-21 $\mathrm{min}, 50-95 \% \mathrm{~B} ; 21-26 \mathrm{~min}$, held at $95 \% \mathrm{~B} ; 26-33 \mathrm{~min}$, balanced to $20 \% \mathrm{~B}$. The flow rate was $0.2 \mathrm{ml} / \mathrm{min}$ and the temperature-controlled column was maintained at $30^{\circ} \mathrm{C}$. Column effluents were monitored at $296 \mathrm{~nm}$ following the injection of $4 \mu \mathrm{l}$ cerebrospinal fluid obtained from the control and treatment groups. MS detection was performed in the positive ion mode. The ESI source parameters were as follows: Ion spray voltage, $+5.0 \mathrm{kV}$; sheath gas flow rate, $40 \mathrm{arb}$; aux gas flow rate, $10 \mathrm{arb}$; capillary temperature, $350^{\circ} \mathrm{C}$; and S-lens RF level, $60 \%$. The mass resolution of Fourier transform was 30,000 with a full scan in the range of $\mathrm{m} / \mathrm{z}, 200-800$. The tandem MS (MS/MS) experiments were set as a datadependent scan. The experimental procedures complied with the Animal Ethics Committee Guidelines of Beijing Animals Science Biology Technology Co., Ltd. (Beijing, China; registration no. 170703002).

Cell viability, morphological alterations and clonogenic survival. Following treatment with various concentrations (10, 20, 30, 40, 100 and $150 \mathrm{ng} / \mathrm{ml}$ ) of arenobufagin and hellebrigenin for $48 \mathrm{~h}$, cell viability was measured using the XTT assay as described previously (31). Relative cell viability was expressed as the ratio of the absorbance at $450 \mathrm{~nm}$ of each treatment group against those of the corresponding untreated control group. The $\mathrm{IC}_{50}$ values of each drug were calculated using GraphPad Prism ${ }^{\circledR} 6.0$ software (GraphPad Software, Inc., La Jolla, CA, USA). With respect to the morphological alterations of U-87 cells, the cells were imaged using an inverted microscope (CKX53; Olympus Corporation, Tokyo, Japan) fitted with a digital camera following treatment with various concentrations $(20,40,100,150$ and $200 \mathrm{ng} / \mathrm{ml})$ of arenobufagin and hellebrigenin for $48 \mathrm{~h}$. Untreated cells were used as the control. Clonogenic survival assays were performed according to a method previously described, with slight modifications (14). Briefly, U-87 cells were seeded at a density of $5 \times 10^{3}$ cells/well in 6 -well plates, and treated with various concentrations $(5,10,20,30$ and $40 \mathrm{ng} / \mathrm{ml})$ of arenobufagin and hellebrigenin for $24 \mathrm{~h}$. Untreated cells were used as the control. The medium was then replaced with fresh DMEM (supplemented with $10 \%$ heat-inactivated FBS, $100 \mathrm{U} / \mathrm{ml}$ penicillin and $100 \mu \mathrm{g} / \mathrm{ml}$ streptomycin) and the cells were allowed to grow for 7-10 days in a humidified 5\% $\mathrm{CO}_{2}$ atmosphere at $37^{\circ} \mathrm{C}$. Following washing gently with PBS twice, the cells were fixed with $0.25 \%$ glutaraldehyde/PBS for $15 \mathrm{~min}$ prior to staining with $0.2 \%$ crystal violet/PBS for $10 \mathrm{~min}$ at room temperature. Following a washout of extra crystal violet with water to get an adequate staining pattern, the images of crystal violet-stained cells were scanned into a computer, followed by dissolution of the violet-stained cells in 1\% SDS. The absorbance of cell lysates was determined at $550 \mathrm{~nm}$. The relative colony formation rate was expressed as the ratio of the absorbance at $550 \mathrm{~nm}$ of each treatment group against those of the corresponding untreated control group.

Cell cycle analysis. Following treatment with various concentrations $(10,20,30$ and $40 \mathrm{ng} / \mathrm{ml})$ of arenobufagin or hellebrigeninfor $48 \mathrm{~h}$, and $20 \mathrm{ng} / \mathrm{ml}$ arenobufagin orhellebrigenin for 24,48 or $72 \mathrm{~h}$, cell cycle analysis was performed using a FACSCanto $^{\mathrm{TM}}$ flow cytometer (BD Biosciences), according to a previous method $(14,21)$. Briefly, cells were washed twice with cold PBS, fixed with $1 \%$ paraformaldehyde/PBS on ice for $30 \mathrm{~min}$, washed twice again with cold PBS, permeabilized in $70 \%(\mathrm{v} / \mathrm{v})$ cold ethanol at $-20^{\circ} \mathrm{C}$ for at least $4 \mathrm{~h}$. Cell pellets were then washed twice with cold PBS following centrifugation 
( $430 \mathrm{x}$ g for $5 \mathrm{~min}$ at $4^{\circ} \mathrm{C}$ ) and incubated with $0.25 \%$ Triton $\mathrm{X}-100$ for $5 \mathrm{~min}$ on ice. Following centrifugation ( $430 \mathrm{x} \mathrm{g}$ for $5 \mathrm{~min}$ at $4^{\circ} \mathrm{C}$ ) and washing with PBS, cells were resuspended in $500 \mu 1$ PI/RNase A/PBS (5 $\mu \mathrm{g} / \mathrm{ml}$ PI and $0.1 \%$ RNase A in PBS) and incubated for $30 \mathrm{~min}$ in the dark at room temperature. A total of 10,000 events were recorded, and FACSDiva ${ }^{\mathrm{TM}}$ software (v6.0; BD Biosciences) and ModFit LT ${ }^{\mathrm{TM}}$ v3.0 (Verity Software House, Inc., Topsham, ME, USA) were used to calculate the number of cells in each $G_{0} / G_{1}, S$ and $G_{2} / M$ phase fraction.

Western blot analysis. For preparation of the protein samples, cell pellets $\left(1-2 \times 10^{6}\right.$ per $110 \mu 1$ buffer $)$ were suspended in Laemmli buffer containing $100 \mathrm{mM}$ DTT, $2 \mu \mathrm{g} / \mathrm{ml}$ leupeptin, $2 \mu \mathrm{g} / \mathrm{ml}$ aprotinin, $1 \mu \mathrm{g} / \mathrm{ml}$ pepstatin, $1 \mathrm{mM}$ PMSF. Cell suspensions were sonicated (Qsonica, LLC, Newtown, CT, USA) with 10 short bursts of $2 \mathrm{sec}$ followed by intervals of $2 \mathrm{sec}$ for cooling. The suspensions were then kept in an ice bath. Sonicated cells were heated in $95^{\circ} \mathrm{C}$ for $5 \mathrm{~min}$, and then centrifuged at $13,000 \mathrm{x} g$ for $15 \mathrm{~min}$ at $4^{\circ} \mathrm{C}$. Protein concentrations of the supernatant were determined according to Bradford's method using the Protein Assay Dye Reagent Concentrate (Bio-Rad Laboratories, Inc.), according to the manufacturer's instructions, using BSA as the standard. Western blot analysis was carried out according to methods previously described (31). Briefly, after separation of proteins (10-20 $\mu \mathrm{g}$ protein/lane) via SDS-PAGE (8, 10 or $12.5 \%$ according to the molecular weight of the target protein), followed by transference to a polyvinylidene difluoride (PVDF) membrane, which was then blocked with 5\% skim milk/PBST (PBS containing $0.5 \%$ Tween-20) for $1 \mathrm{~h}$ at room temperature. Protein bands were detected using the following primary antibodies: Mouse anti-human $\beta$-actin (1:5,000 dilution; cat. no. A-5441; Sigma-Aldrich; Merck KGaA, Darmstadt, Germany), rabbit anti-human Cdc25c (1:1,000 dilution; cat. no. 4688), rabbit anti-human p27 (1:1,000 dilution; cat. no. 2552), mouse antihuman Cyclin B1 (1:2,000 dilution; cat. no. 4135), mouse anti-human survivin (1:1,000 dilution; cat. no. 2802), rabbit anti-human phospho-Akt (Ser473) (1:2,000 dilution; cat. no. 4060) and Akt (1:1,000 dilution; cat. no. 4691), rabbit anti-human phospho-p38 (Thr180/Tyr182, 1:1,000 dilution; cat. no. 9211) and p38 (1:1,000 dilution; cat. no. 9212), rabbit anti-human phospho-MK2 (Thr334) (1:1,000 dilution; cat. no. 3041), rabbit anti-human phospho-ERK (Thr202/Tyr2042) (1:2,000 dilution; cat. no. 4370) and ERK (1:1,000 dilution; cat. no. 4695; all from Cell Signaling Technology, Inc., Danvers, MA, USA). PVDF membranes containing blotted protein bands were incubated overnight with the respective primary antibody at $4^{\circ} \mathrm{C}$, followed by the appropriate horseradish peroxidase-conjugated secondary antibody (antimouse $\operatorname{IgG}$, 1:3,000 dilution, cat. no. A5906; anti-rabbit IgG, 1:3,000 dilution, cat. no. A0545; both from Sigma-Aldrich; Merck $\mathrm{KGaA}$ ) for $1 \mathrm{~h}$ at room temperature, and then detected with an enhanced chemiluminescence (ECL) analysis system (Amersham; GE Healthcare Life Sciences, Chalfont, UK).

Lactate dehydrogenase ( $L D H)$ assay. Following treatment with various concentrations $(10,20,40,100,150$ and $200 \mathrm{ng} / \mathrm{ml})$ of arenobufagin or hellebrigenin for $48 \mathrm{~h}$ as described in the previous section of the cell viability assay, LDH leakage from U-87 cells was measured using a LDH cytotoxicity detection kit (Wako Pure Chemical Industries, Ltd.) according to the method previously described with slight modifications (31). Briefly, culture medium served as the negative control (NC). Culture supernatants $(\mathrm{S})$ were collected by centrifugation at $450 \mathrm{x} \mathrm{g}$ for $5 \mathrm{~min}$ at $4^{\circ} \mathrm{C}$ and stored at $-80^{\circ} \mathrm{C}$ until use. Cultured cells without treatment were lysed in the culture medium containing $0.2 \%$ Tween-20, and the cell lysate was used as the non-damaged positive control (PC) following centrifugation at $12,000 \mathrm{x} \mathrm{g}$ for $5 \mathrm{~min}$ at $4^{\circ} \mathrm{C}$. In order to avoid the influence of Tween-20, culture medium containing $0.2 \%$ Tween-20 served as the negative control for PC and was referred to as NCT. Samples were diluted 16-fold with PBS and $50 \mu \mathrm{l}$ of the diluted solution was transferred into wells of a 96-well plate. LDH activities were determined by adding $50 \mu \mathrm{l}$ reaction reagent from the kit, followed by incubation at room temperature for $30 \mathrm{~min}$. The reaction was stopped by the addition of $100 \mu \mathrm{l}$ stopping solution provided with the kit at room temperature, and the absorbance at $560 \mathrm{~nm}$ was measured with a microplate reader (EMax ${ }^{\circledR}$ Plus; Molecular Devices, LLC, Sunnyvale, CA, USA). Cell damage was calculated as a percentage of $\mathrm{LDH}$ leakage from damaged cells using the following formula: (S-NC)/(PC-NCT) x 100.

DNA fragmentation analysis. DNA fragmentation analysis was performed according to a method described previously (32). Briefly, between $5 \times 10^{5}$ and $1 \times 10^{6}$ cells were used for the DNA preparation. The cells were suspended in $500 \mu 1$ lysis buffer (50 mM Tris-HCl, pH 7.8, 10 mM EDTA-2Na, 0.5\% sodium-N-lauroyl sarcosinate). The suspension was incubated in an ice bath for $30 \mathrm{~min}$ following the addition of $50 \mu \mathrm{l}$ of $10 \%$ SDS with gentle agitation every $5 \mathrm{~min}$. The lysates were incubated successively at $50^{\circ} \mathrm{C}$ for 90 min with proteinase $\mathrm{K}$ $(1 \mathrm{mg} / \mathrm{ml})$, at $50^{\circ} \mathrm{C}$ for $30 \mathrm{~min}$ with RNase $\mathrm{A}(1 \mathrm{mg} / \mathrm{ml})$ and at $60^{\circ} \mathrm{C}$ for $15 \mathrm{~min}$ following the addition of the same volume of $\mathrm{NaI}$ solution [6.0 M NaI in $26 \mathrm{mM}$ Tris- $\mathrm{HCl}, \mathrm{pH} 8.0$, $13 \mathrm{mM}$ EDTA-2Na, $10 \mathrm{mg} / \mathrm{ml}$ of bovine glycogen (Nacalai Tesque, Inc., Kyoto, Japan)]. DNA was precipitated by addition of an equal volume of $100 \%$ isopropanol. DNA pellets were successively washed with $50 \%$ isopropanol, $100 \%$ isopropanol and 70\% ethanol. Extracted DNA was dissolved in TE buffer (10 mM Tris-HCl, pH 7.8, 1 mM EDTA), and the DNA concentrations were determined by staining with Hoechst 33258 as described (33). The DNA samples ( $20 \mu \mathrm{g}$ DNA in $20 \mu \mathrm{l}$ TE buffer) and 100 bp DNA ladder (Invitrogen; Thermo Fisher Scientific, Inc.) as a DNA size marker were electrophoresed on a $2 \%$ agarose $\mathrm{X}$ gel using TBE buffer (89 mM Tris, $89 \mathrm{mM}$ boric acid, 2 mM EDTA). Gels were visualized using $0.5 \mu \mathrm{g} / \mathrm{ml}$ ethidium bromide staining (at room temperature, $30 \mathrm{~min}$ ), followed by viewing under a Luminograph II chemiluminescent imaging system (ATTO Corporation, Tokyo, Japan).

Statistical analysis. Experiments were independently repeated three times, and the results are presented as the means \pm standard deviation of three assays. Statistical analysis was performed using GraphPad Prism ${ }^{\circledR} 6$ software. The Student's t-test was used to compare sample means between two groups, and one-way analysis of variance followed by Dunnett's post hoc test was used to compare sample means among three or more groups. $\mathrm{P}<0.05$ was considered to indicate a statistically significant difference. 
A
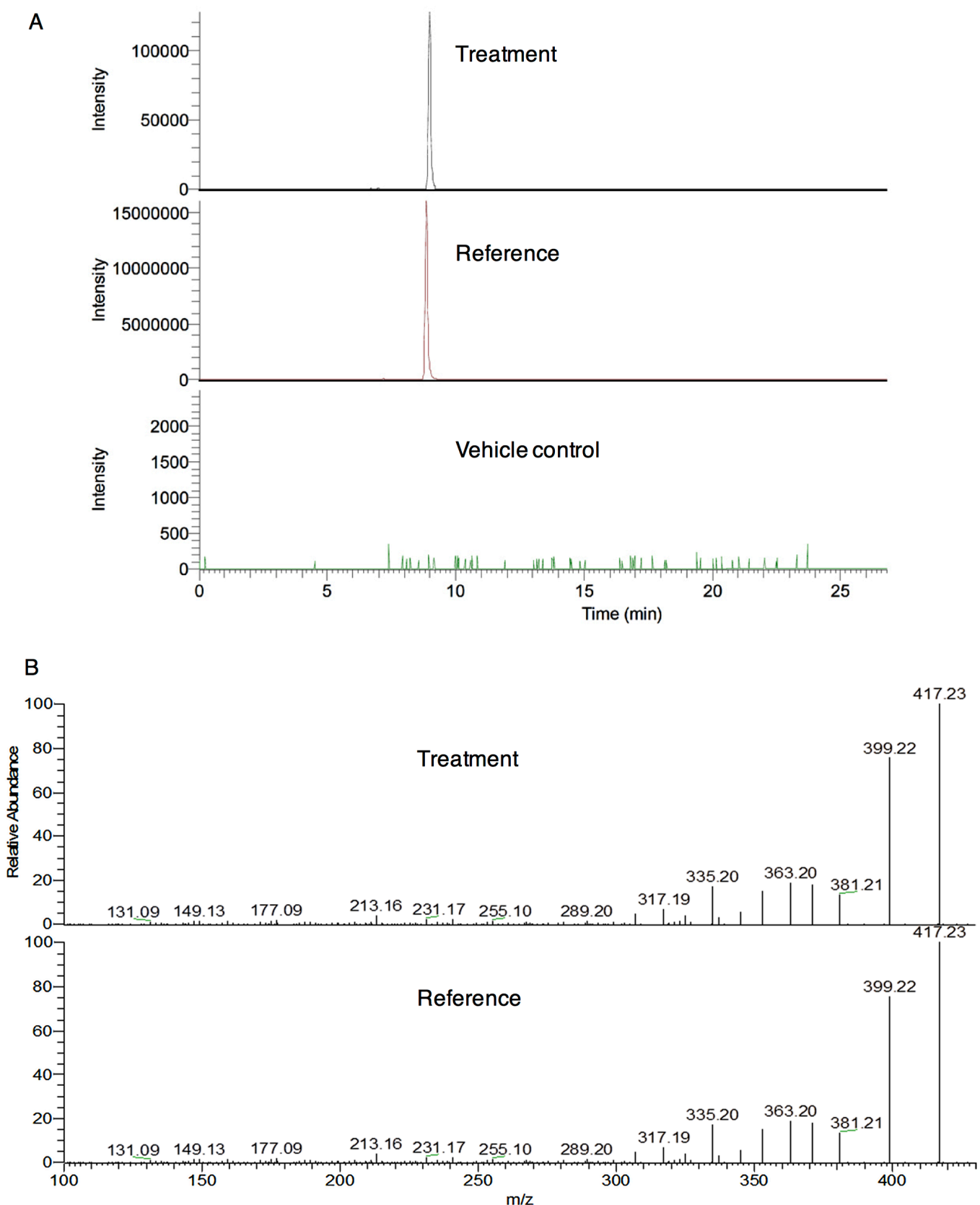

Figure 1. Detection of Areno in cerebrospinal fluids by UHPLC-MS/MS analysis. A representative extracted ion chromatogram profile is shown from three independent experiments. Reference standard was prepared by dissolving the Areno in methanol at the concentration of $10 \mu \mathrm{g} / \mathrm{ml}$. (A) Areno in cerebrospinal fluid of Areno-administered rats (upper), the reference standard (middle) and the vehicle control (saline) (lower) were extracted, (B) followed by the MS/MS experiments for further identification by comparing their liquid chromatography-mass spectrometric behaviors. Treatment, Areno-administered rats; reference, reference standard; vehicle control, saline-administered rats; UHPLC, ultra high performance liquid chromatography; MS/MS, tandem mass spectrometry; Areno, arenobufagin.

\section{Results}

Presence of arenobufagin, but not hellebrigenin, in cerebrospinal fluid of rats. First, whether the two active bufadienolides were able to cross the BBB was investigated. The $[\mathrm{M}+\mathrm{H}]^{+}$ion of arenobufagin at $m / z 417.2264\left(\mathrm{C}_{24} \mathrm{H}_{33} \mathrm{O}_{6}\right.$, Cal.417.2272, error $-1.88 \mathrm{ppm}$ ) with a retention time of $8.97 \mathrm{~min}$ was only detected in the cerebrospinal fluid of rats who received a single oral dose of arenobufagin, instead of saline (vehicle control) (Fig. 1A). However, the $[\mathrm{M}+\mathrm{H}]^{+}$ion of hellebrigenin at $\mathrm{m} / \mathrm{z} 417.2277$ $\left(\mathrm{C}_{24} \mathrm{H}_{33} \mathrm{O}_{6}\right.$, Cal.417.2272, error $\left.1.26 \mathrm{ppm}\right)$ with a retention time of 8.91 min was hardly detected in the cerebrospinal fluid of rats who received a single oral dose of hellebrigenin due to its very low signal intensity. The further identification of arenobufagin in cerebrospinal fluids was performed using MS/MS experiments (Fig. 1B). These results indicated that arenobufagin, but not hellebrigenin, were able to cross the BBB.

Cytotoxic effects of arenobufagin and hellebrigenin in human glioblastoma cell line U-87. A significant decrease in cell viability was observed in a dose-dependent manner in U-87 cells following treatment with various concentrations of arenobufagin and hellebrigenin for $48 \mathrm{~h}$. The $\mathrm{IC}_{50}$ values of arenobufagin and hellebrigenin were $24.9 \pm 2.8 \mathrm{ng} / \mathrm{ml}$ and $23.5 \pm 2.4 \mathrm{ng} / \mathrm{ml}$, 
A

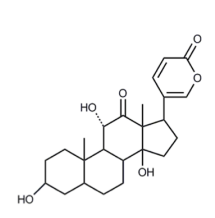

Arenobufagin



Hellebrigenin
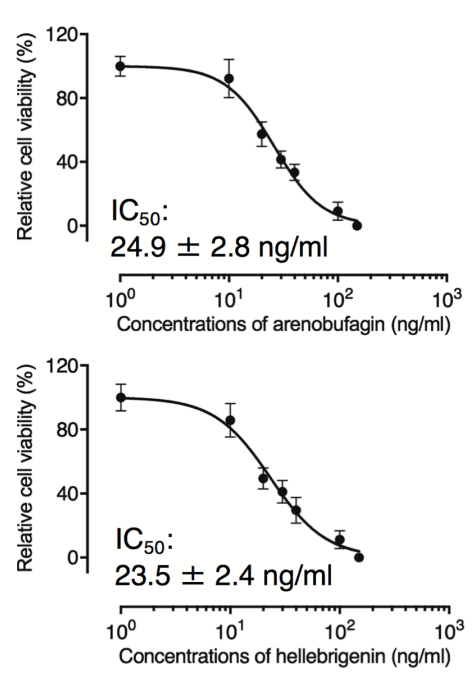

$\mathrm{C}$


E Arenogufagin

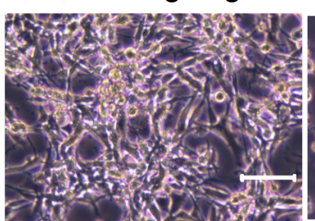

0



20

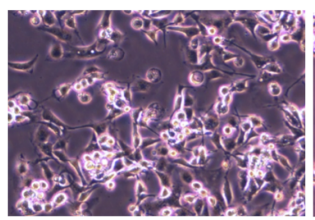

40

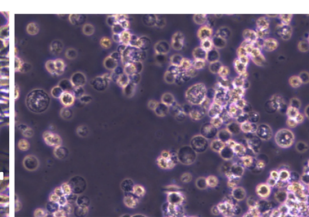

100

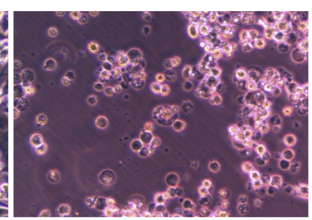

150



200

\section{F Hellrebrigenin}

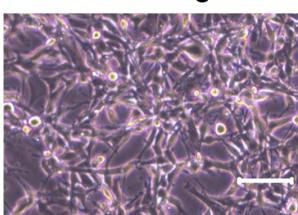

0



20

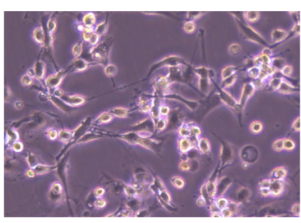

40

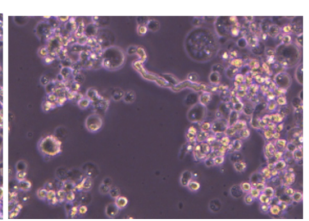

100

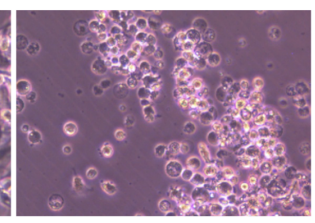

150

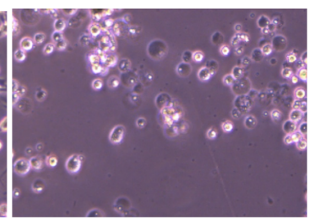

200

G

Control (0)



Arenogufagin (150)

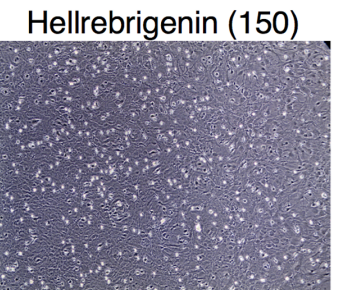

Figure 2. Cytotoxic effects of Areno and Helle in human glioblastoma cell line, U-87. Cell viability of U-87 [(A) Areno treatment; (B) Helle treatment and primary mouse astrocytes; (C) Areno treatment; (D) Helle treatment] was determined using an XTT assay following treatment with various concentrations $(10,20,30,40,100$ and $150 \mathrm{ng} / \mathrm{ml})$ of each single drug for $48 \mathrm{~h}$. Relative cell viability was calculated as the ratio of the absorbance at $450 \mathrm{~nm}$ of each treatment group against those of the corresponding untreated control group. Data are presented as the mean \pm standard deviation $(\mathrm{n} \geq 3)$. ${ }^{8} \mathrm{P}<0.001$ and ${ }^{\dagger} \mathrm{P}<0.0001 \mathrm{vs}$. control. Following treatment with various concentrations (20,40, 100,150 and $200 \mathrm{ng} / \mathrm{ml}$ ) of (E) Areno and (F) Helle for $48 \mathrm{~h}$, the morphological alterations of U-87 were evaluated as described in the materials and methods. (G) The morphological alterations of primary mouse astrocytes were also evaluated following treatment with as high as $150 \mathrm{ng} / \mathrm{ml}$ of Areno and Helle. Representative images of the morphological alterations are shown from three independent experiments. Scale bar, $100 \mu \mathrm{m}$. Areno, arenobufagin; Helle, hellebrigenin.

respectively (Fig. 2A and $\mathrm{B}$ ). In comparison, under the same treatment conditions, no cytocidal effect was observed in mouse primary astrocytes when treated with arenobufagin (Fig. 2C), and a slight increase in viability was observed following treatment with hellebrigenin at concentrations $>10 \mathrm{ng} / \mathrm{ml}$ (Fig. 2D). Morphological alterations of U-87 cells were also observed using an inverted microscope. As shown in Fig. 2E and F, treatment with arenobufagin and hellebrigenin at concentrations $>100 \mathrm{ng} / \mathrm{ml}$ for $48 \mathrm{~h}$, caused a large number of U-87 cells to detach from the plate. In contrast, concentrations $<40 \mathrm{ng} / \mathrm{ml}$ of each drug exhibited little effect on cell morphology, although an evident decrease in the number of cells/field was observed, 



C

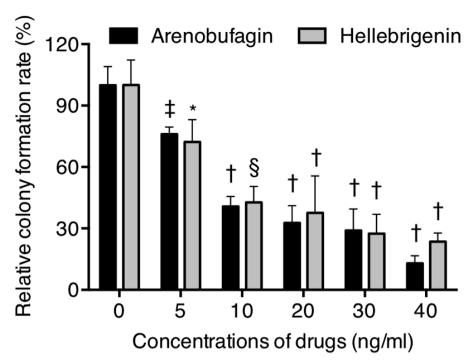

Figure 3. Inhibition of colony formation of U-87 cells by Areno and Helle. The cells were seeded at $5 \times 10^{3}$ cells/well in 6 -well plates following treatment with indicated concentrations (5, 10, 20,30 and $40 \mathrm{ng} / \mathrm{ml}$ ) of (A) Areno and (B) Helle for $24 \mathrm{~h}$. Representative images of the clonogenic assays are shown from three independent experiments. (C) The relative colony formation rate was expressed as the ratio of the absorbance at $550 \mathrm{~nm}$ of each treatment group against those of the corresponding untreated control group as described in the materials and methods. Data are presented as the means \pm standard deviation from three independent experiments. ${ }^{*} \mathrm{P}<0.05,{ }^{+} \mathrm{P}<0.01,{ }^{\$} \mathrm{P}<0.001$ and ${ }^{\mathrm{P}} \mathrm{P}<0.0001$ vs. respective control. Areno, arenobufagin; Helle, hellebrigenin.

indicating an inhibition of cell viability. In comparison, almost no morphological alterations were observed in the primary astrocytes following treatment with the two bufadienolides at concentrations $\leq 150 \mathrm{ng} / \mathrm{ml}$ (Fig. 2G).

Inhibition of colony formation of $U-87$ cells by arenobufagin and hellebrigenin. To explore whether exposure to arenobufagin and hellebrigenin suppressed the surviving fraction of U-87 cells, a colony formation assay was performed. As shown in Fig. 3, significant suppression of the colony numbers of U-87 was observed following long-term treatment with arenobufagin or hellebrigenin, at concentrations $\geq 5 \mathrm{ng} / \mathrm{ml}$, indicating their potency against the survival of the cells.

Effect of arenobufagin and hellebrigenin on the cell cycle, and the expression level of cell cycle-associated proteins in U-87 cells. To explore whether cell cycle arrest is involved in the cytotoxic effects of arenobufagin and hellebrigenin, cell cycle analyses were performed using flow cytometry (Figs. 4 and 5). In comparison with control group (untreated cells), a significant increase in the number of cells in the $G_{2} / M$ phase was observed (Figs. 4A and $\mathrm{C}$, and 5A and $\mathrm{C}$ ) following treatment with various concentrations of the two drugs for $48 \mathrm{~h}$. Concomitantly, a significant decrease in the number of cells in the $G_{0} / G_{1}$ and $S$ phase was also observed (Figs. 4A and $C$, and $5 \mathrm{~A}$ and $\mathrm{C}$ ). Furthermore, following treatment with arenobufagin or hellebrigenin at $20 \mathrm{ng} / \mathrm{ml}$, which was almost equal to their $\mathrm{IC}_{50}$ values, for 24,48 and $72 \mathrm{~h}, \mathrm{G}_{2} / \mathrm{M}$ cell cycle arrest-inducing activity of each drug was observed at 24 -h post- treatment, which reached the maximum at 48-h post-treatment, and was sustained for up to $72 \mathrm{~h}$ (Figs. 4B and D, and 5B and D). A significant decrease in the number of cells in the $G_{0} / G_{1}$ and $\mathrm{S}$ phase was also concomitantly observed (Figs. 4B and D, and $5 \mathrm{~B}$ and D). As shown in Fig. 6, compared with the control group, the expression of $\mathrm{Cdc} 25 \mathrm{C}$ and Cyclin B1 was remarkably downregulated following treatment with arenobufagin or hellebrigenin in a dose-dependent manner, although almost no evident alteration was observed in the expression levels of p27. Similarly, a dose-dependent downregulation in the expression of survivin was also observed.

Effect of arenobufagin or hellebrigenin on $\mathrm{LDH}$ release from $U-87$ cells. The release of $\mathrm{LDH}$ provides an accurate measure of the cell membrane integrity and cell viability $(13,14,31)$. Following treatment with various concentrations of arenobufagin and hellebrigenin for $48 \mathrm{~h}$, LDH leakage analysis was performed to examine whether the treatments affected cell membrane integrity. A dose-dependent increased in LDH leakage was observed in U-87 cells treated with arenobufagin or hellebrigenin (Fig. 7). Notably, no significant difference was observed between cells treated with each drug at $20 \mathrm{ng} / \mathrm{ml}$ and their respective control group $(0 \mathrm{ng} / \mathrm{ml})$, indicating that cell membrane damage was more likely due to relatively high concentrations, but not relatively low concentrations, of each drug.

Effect of arenobufagin or hellebrigenin on DNA fragmentation in U-87 cells. To explore whether apoptosis is involved in the cytotoxic effects of arenobufagin and hellebrigenin, 


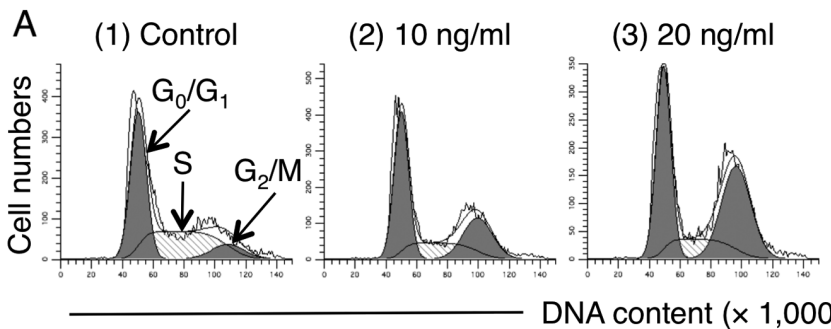

(4) $30 \mathrm{ng} / \mathrm{ml}$

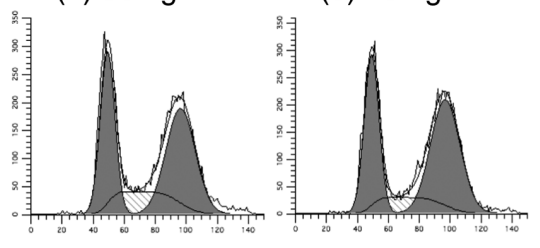

00)
B (1) $24 \mathrm{~h}$ control
(3) $48 \mathrm{~h}$ control

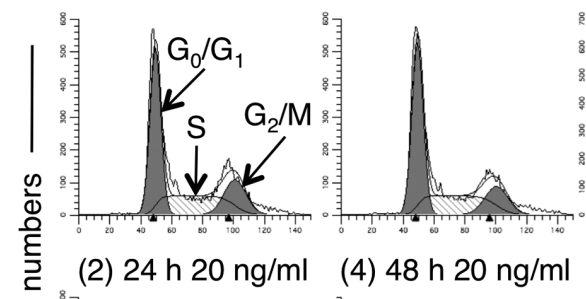

(5) $72 \mathrm{~h}$ control

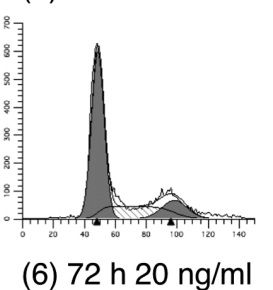

C

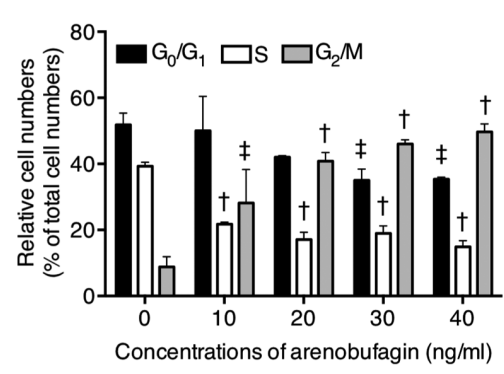

D

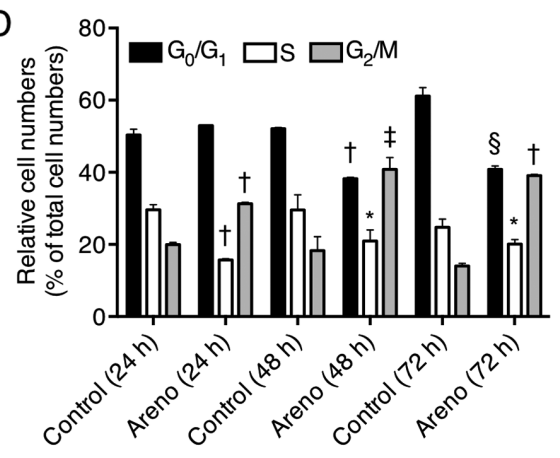

Figure 4. Effect of Areno on the U-87 cell cycle profile. Following treatment with (A) various concentrations of Areno (10, 20,30 and 40 ng/ml) for 48 h, or (B) $20 \mathrm{ng} / \mathrm{ml}$ Areno for 24, 48 and $72 \mathrm{~h}$, cell cycle analysis was performed using a FACSCanto ${ }^{\mathrm{TM}}$ flow cytometer as described in the materials and methods ModFit LT ${ }^{\mathrm{TM}}$ v3.0 was then used to calculate the number of cells in each $\mathrm{G}_{0} / \mathrm{G}_{1}, \mathrm{~S}$ and $\mathrm{G}_{2} / \mathrm{M}$ phase fraction following treatment (C) with the indicated concentrations of Areno for $48 \mathrm{~h}$, or (D) with $20 \mathrm{ng} / \mathrm{ml}$ Areno for the indicated time periods. A representative FACS histogram from three independent experiments is shown. Data are presented as the means \pm standard deviation from three independent experiments. ${ }^{*} \mathrm{P}<0.05,{ }^{\ddagger} \mathrm{P}<0.01,{ }^{\circledR} \mathrm{P}<0.001$ and ${ }^{\dagger} \mathrm{P}<0.0001 \mathrm{vs}$. the respective control. Areno, arenobufagin.

DNA fragmentation analysis was preformed using DNA gel electrophoresis. As shown in Fig. 8, no DNA fragmentation was observed in U-87 cells when treated with arenobufagin or hellebrigenin, even at the concentrations $>100 \mathrm{ng} / \mathrm{ml}$, which significantly induced a large number of U-87 cells to lose their adhesive properties (Fig. 2E and F) and LDH release (Fig. 7). These results indicated that apoptosis induction was less likely to contribute to the cytotoxicity caused by arenobufagin or hellebrigenin regardless of the drug concentration. These results were also supported by the cell cycle analysis, demonstrating almost no accumulation of cells in the sub-G1 phase, which typically represents apoptotic cells (Figs. 4 and 5).

Effect of arenobufagin or hellebrigenin on the activation of the PI3K/Akt and MAPK signaling pathway in U-87 cells. To explore whether the PI3K/Akt and/or MAPK signaling pathway are involved in the cytocidal effects of arenobufagin and hellebrigenin, the activation of Akt, p38, Erk and JNK was determined in U-87 cells following treatment with various concentrations of arenobufagin and hellebrigenin for $48 \mathrm{~h}$. As shown in Fig. 9, a substantial increase in the expression levels of phospho-p38 MAPK over the endogenous levels was detected in the cells when treated with arenobufagin or hellebrigenin, although almost no alterations in the expression levels of total p38 MAPK expression was observed. Furthermore, similar phenomena were observed in the expression levels of phospho-MAPKAPK2 (MK2), a direct downstream target of p38 MAPK. In contrast, the expression level of phosphoAkt was slightly increased along with a modest decrease in the total Akt expression. Similarly, a modest increase in the expression level of phospho-Erk and total Erk was also observed in the cells, although the highest concentrations of hellebrigenin $(40 \mathrm{ng} / \mathrm{ml})$ slightly downregulated the expression of phospho-Erk. These results indicated that the activation of 



Figure 5. Effect of Helle on the cell cycle profiling in U-87 cells. Following treatment with various concentrations of Helle (10, 20, $30 \mathrm{and} 40 \mathrm{ng} / \mathrm{ml})$ for $48 \mathrm{~h} \mathrm{(A),} \mathrm{or} 20 \mathrm{ng} / \mathrm{ml}$ Helle for 24, 48 and $72 \mathrm{~h}$ (B), cell cycle analysis was performed using a FACSCanto flow cytometer as described in Materials and methods. ModFit LT ${ }^{\mathrm{TM}}$ v3.0 was then used to calculate the number of cells in each $\mathrm{G}_{0} / \mathrm{G}_{1}, \mathrm{~S}$ and $\mathrm{G}_{2} / \mathrm{M}$ phase fraction following treatment $(\mathrm{C})$ with the indicated concentrations of Helle for $48 \mathrm{~h}$, or (D) with $20 \mathrm{ng} / \mathrm{ml}$ Helle for the indicated time periods (D). A representative FACS histogram from three independent experiments is shown. Data are presented as the mean \pm standard deviation from three independent experiments. ${ }^{*} \mathrm{P}<0.01,{ }^{\S} \mathrm{P}<0.001$ and ${ }^{\dagger} \mathrm{P}<0.0001$ vs. respective control. Helle, hellebrigenin.

p38 MAPK was involved in the cytocidal effects of arenobufagin and hellebrigenin, although the partial participation of Akt and Erk may not be completely excluded. In addition, the expression level of phospho-JNK was not detected regardless of the presence or absence of each drug, indicating that there was no association between JNK and the cytocidal effects of the two drugs.

Enhancement of cytotoxicity of arenobufagin and hellebrigenin by a specific inhibitor of p38 MAPK in U-87 cells. To provide further confirm the direct involvement of p38 MAPK in the cytocidal effects of arenobufagin and hellebrigenin, alterations to cell viability were determined in U-87 cells following treatment for $48 \mathrm{~h}$ with $20 \mathrm{ng} / \mathrm{ml}$ arenobufagin or hellebrigenin in the presence or absence of various concentrations of SB203580, a specific inhibitor of p38 MAPK. Consistent with the $\mathrm{IC}_{50}$ values of each drug (Fig. 2), treatment with $20 \mathrm{ng} / \mathrm{ml}$ of arenobufagin or hellebrigenin alone significantly reduced cell viability by $\sim 50 \%$ (Fig. 10A-C). Compared with the groups treated with arenobufagin or hellebrigenin alone, combining various concentrations of $\mathrm{SB} 203580(1,5$ and $10 \mu \mathrm{M})$ with each drug significantly enhanced the cytotoxicities of the two drugs (Fig. 10A-C). Although significant reductions in the viability following treatment with each drug in combination with SB202474, a negative control for SB203580, were also observed compared with single drug treatment, the efficacy of each drug was increased more by the addition of SB203580 in comparison with SB202474, indicating the critical role of p38 MAPK. Notably, a dose-dependent decease in the cell viability was observed in cells treated with various concentrations of SB202580 $(1,5$ and $10 \mu \mathrm{M})$ alone, but not SB202474 alone. In order to evaluate whether there was an association between the activation of the p38 MAPK pathway and other cellular responses, alterations to cell cycle arrest, LDH 

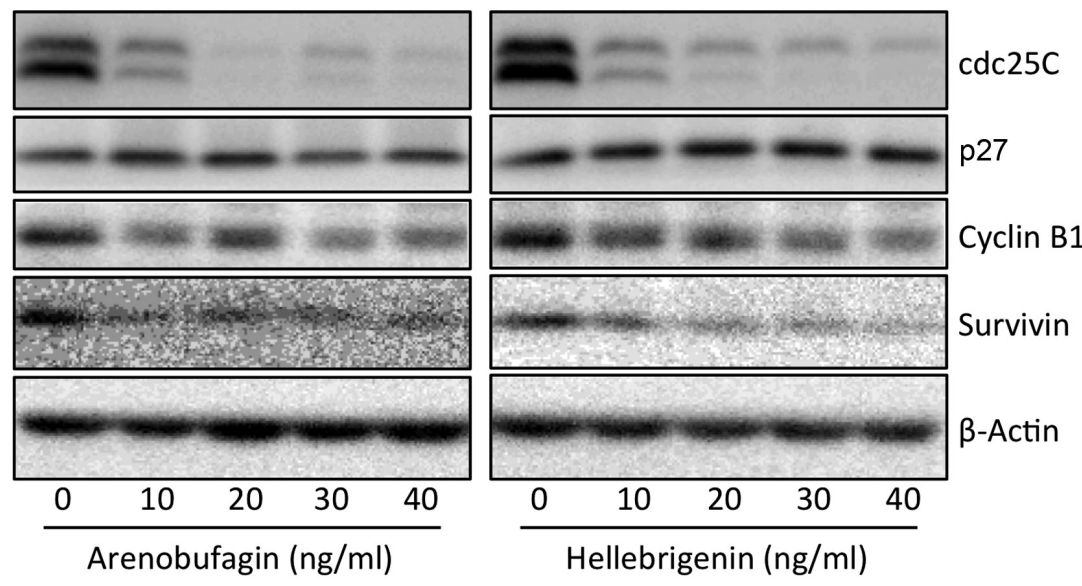

Figure 6. Effect of Areno or Helle on the expression level of cell cycle-associated proteins in U-87 cells. Following treatment with various concentrations (10, 20,30 and $40 \mathrm{ng} / \mathrm{ml}$ ) of Areno and Helle for $48 \mathrm{~h}$, the expression profiles of cell cycle-associated proteins were analyzed using western blotting. A representative image of the expression profile of each protein is shown from three independent experiments. Areno, arenobufagin; Helle, hellebrigenin.



Figure 7. Effect of Areno or Helle on LDH release from U-87 cells. Following treatment with various concentrations $(10,20,40,100,150$ and $200 \mathrm{ng} / \mathrm{ml})$ of Areno and Helle for $48 \mathrm{~h}, \mathrm{LDH}$ leakage was measured using the LDH-Cytotoxic kit as described in the materials and methods. Data are presented as the means \pm standard deviation from three independent experiments. ${ }^{*} \mathrm{P}<0.01$ and ${ }^{\dagger} \mathrm{P}<0.0001$ vs. the respective control. Areno, arenobufagin; Helle, hellebrigenin.

leakage and DNA fragmentation were further determined in cells. No alteration in LDH leakage (Fig. 10D), $\mathrm{G}_{2} / \mathrm{M}$ cell cycle arrest (Fig. 11) or DNA fragmentation (Fig. 8B and C) was observed in the cells treated with a combination of each drug and SB203580 when compared with treatment with each drug alone, indicating no association between the activation of p38 MAPK signaling pathway and these cellular responses.

\section{Discussion}

Due to the restrictive nature of the BBB, the delivery of anticancer drugs to the central nervous system remains a major challenge to the treatment of glioblastoma. Much effort has been directed towards developing a novel system such as nanoparticulate formulation for brain delivery of drugs $(34,35)$. In the present study, the qualitative assessment demonstrated for the first time the existence of arenobufagin, but not hellebrigenin, in the cerebrospinal fluid of rats who received a single oral dose of the drug, directly indicating the capacity of arenobufagin to cross the BBB. In fact, previous biodistribution studies have demonstrated that other active bufadienolide compounds with similar structures to arenobufagin, including bufotalin, bufalin, resibufogenin and cinobufagin, were primarily distributed in the brain, lung and spleen $(35,36)$, and the longest retention was observed in the brain (35), as a result of the intravenous delivery of these compounds to mice. Compared with the chemical structure of arenobufagin, hellebrigenin contains a formyl group instead of a methyl group at position 19 of the molecule. Thus, it was suggested that the difference in their chemical structure may be associated with the differing ability to cross the BBB, although further investigation is required to confirm this. Collectively, these results indicate the possibility of the clinical application of arenobufagin for patients with glioblastoma. However, quantitative evaluation of arenobufagin levels in cerebrospinal fluid is required to clarify whether its exact concentration is adequate to achieve the inhibition of brain cancer cell viability.

It was further demonstrated that arenobufagin and hellebrigenin exhibited similar dose-dependent cytotoxic effects against U-87 cells as evidenced by the XTT assay, as well as morphological alterations and colony formation inhibitory properties. In comparison, the same treatments did not cause any detectable toxic effects in mouse primary astrocytes, and the addition of hellebrigenin even resulted in enhanced viability of the cells, although we are unable to provide a plausible explanation for the phenomena at present. Similarly, it was previously demonstrated that arenobufagin possesses selective cytotoxic activity against human tumor cells, including U-87 and a pancreatic cancer cell line SW1990 rather than PBMCs (9). These results provide further evidence for the efficacy of arenobufagin and hellebrigenin against cancerous glial cells with high potency, selectivity and tolerability, although elucidation of their physiological mechanisms underlying differential responses between tumor and normal cells is required. In addition, Meng et al (8) demonstrated that cinobufacini possesses effective anticancer activity in patients with hepatocellular carcinoma and pancreatic cancer with low toxicity and few side effects. Collectively, these findings provide a rationale for the clinical application of arenobufagin and/or hellebrigenin for patients with glioblastoma.

Active bufadienolide compounds, including bufalin, arenobufagin and hellebrigenin, have been demonstrated to induce $G_{2} / M$ cell cycle arrest in human hepatocellular 


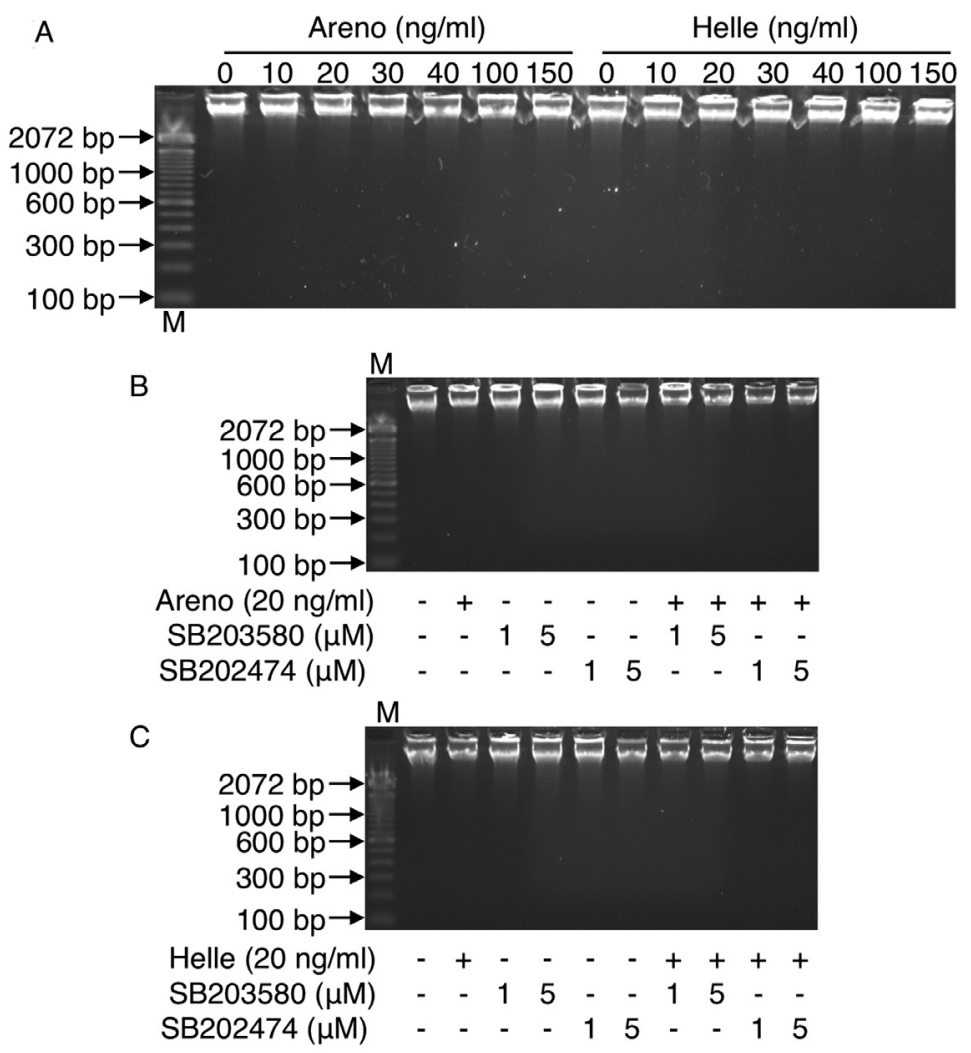

Figure 8. Effect of Areno or Helle on DNA fragmentation in U-87 cells. A representative electrophoretic profile is shown from three independent experiments following treatment with (A) various concentrations (10, 20,30, 40, 100 and $150 \mathrm{ng} / \mathrm{ml}$ ) of Areno and Helle, or $20 \mathrm{ng} / \mathrm{ml}$ of either (B) Areno or (C) Helle in the presence or absence of SB203580, a specific inhibitor of p38 MAPK and its negative control SB202474 (1 and $5 \mu \mathrm{M}$, respectively) for $48 \mathrm{~h}$. Areno, arenobufagin; Helle, hellebrigenin.
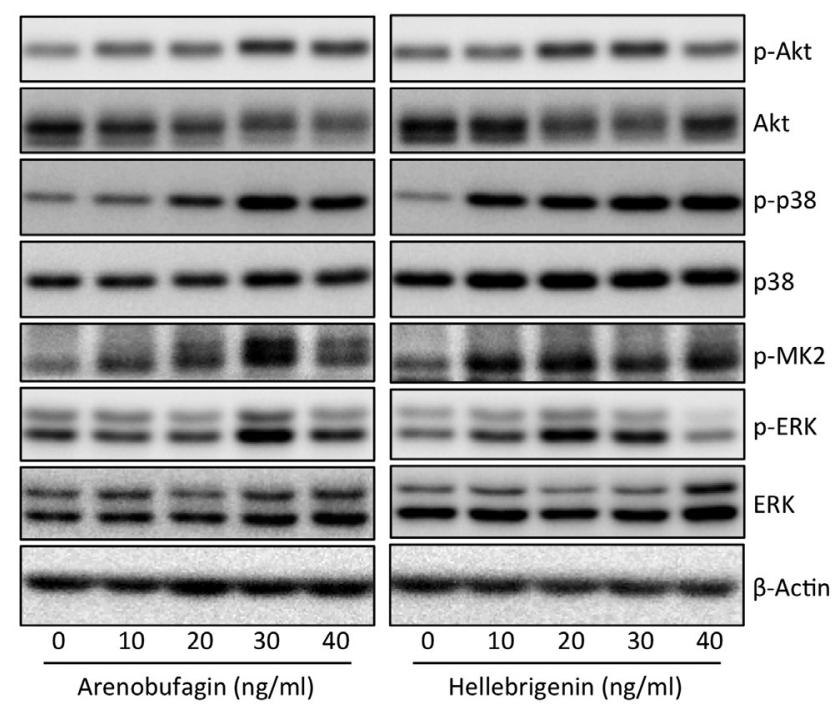

Figure 9. Effect of Areno or Helle on the activation of the PI3K/Akt and MAPK signaling pathways in U-87 cells. Following treatment with various concentrations (10, 20, 30 and $40 \mathrm{ng} / \mathrm{ml}$ ) of Areno and Helle for $48 \mathrm{~h}$, the expression profiles of both phosphorylated and/or total forms of Akt, p38, MK2 and Erk were analyzed using western blotting. Representative images of the expression profile of each protein are shown from three independent experiments. p-Akt, p-p38, p-MK2 and p-Erk represent phospho-Akt, phospho-p38, phospho-MK2 and phospho-Erk, their phosphorylated active form, respectively. Areno, arenobufagin; Helle, hellebrigenin.

carcinoma cells (16-18). In line with these previous findings, treatment with arenobufagin or hellebrigenin caused dose- and time-dependent accumulation of cells in the $\mathrm{G}_{2} / \mathrm{M}$ phase, along with a significant decrease in the number in $\mathrm{G}_{0} / \mathrm{G}_{1}$ and $\mathrm{S}$ phase cells. Concomitantly, a remarkable downregulation of the expression levels of Cdc25C and Cyclin B1, key regulators involved in the $\mathrm{G}_{2} / \mathrm{M}$ cell cycle transition (37,38), was further observed in the treated cells compared with the control (untreated cells). A number of previous studies have demonstrated that in glioblastoma cell lines, downregulation of the expression levels of $\mathrm{Cdc} 25 \mathrm{C}$ and Cyclin B1 has been implicated in the $\mathrm{G}_{2} / \mathrm{M}$ phase arrest induced by various antitumor agents, including arsenic trioxide (39), tivozanib, a pan-inhibitor of vascular endothelial growth factor (40), and knockdown of $\beta$-arrestin 1, a mediator of tachykinin receptor neurokinin-1 signaling pathway responsible for cell proliferation (41). Survivin, an important cancer-associated protein, is highly expressed in the majority of human tumor cells, including primary human glioblastoma cells (19), and its inhibition has been considered as a compelling strategy for cancer therapy (42). It has been demonstrated that nuclear survivin expression may be a useful biomarker for predicting the prognosis in patients with glioblastoma (43). Furthermore, suppression of survivin by small interfering RNA results in reduced proliferation and $\mathrm{G}_{2} / \mathrm{M}$ cell cycle arrest in human cancer cells, including HeLa, a human cervical cancer cell line, and MCF-7, a human breast cancer cell line (44). In the present study, similar to Cdc25C and Cyclin B1, a dose-dependent downregulation of survivin expression was observed, suggesting survivin serves an important role in the $\mathrm{G}_{2} / \mathrm{M}$ phase arrest induced by arenobufagin and hellebrigenin. 


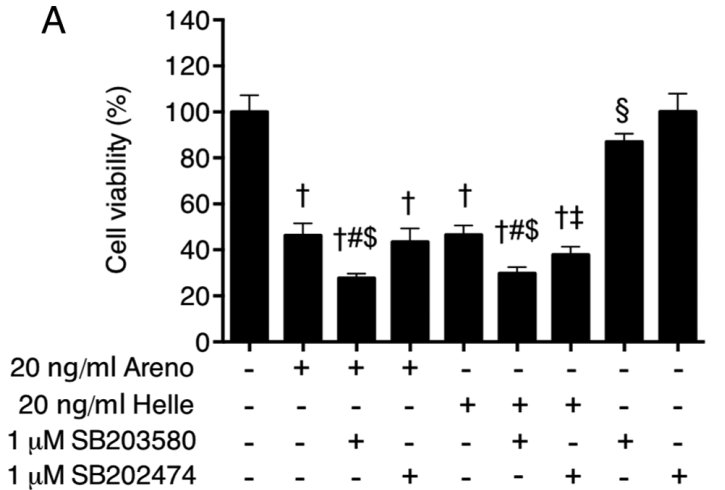

C





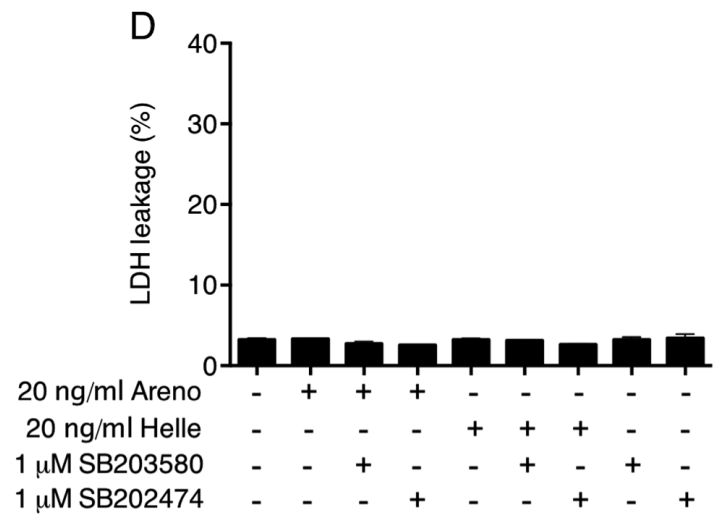

Figure 10. Enhancement of cytotoxicity of Areno and Helle by a specific inhibitor of p38 MAPK in U-87 cells. Cell viability was determined by XTT assay following treatment with Areno and Helle at the concentrations of $20 \mathrm{ng} / \mathrm{ml}$ in the presence or absence of (A) $1 \mu \mathrm{M}$, (B) $5 \mu \mathrm{M}$ or (C) $10 \mu \mathrm{M}$ of SB203580, a specific inhibitor of p38 MAPK and its negative control SB202474 for $48 \mathrm{~h}$. (D) LDH leakage was also measured using the LDH-Cytotoxic test kit as described in Materials and methods following treatment with $20 \mathrm{ng} / \mathrm{ml}$ of Areno and Helle in the presence or absence of $1 \mu \mathrm{M} \mathrm{SB} 203580$ and SB202474 for $48 \mathrm{~h}$.

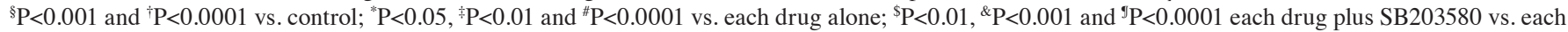
drug plus SB202474. Areno, arenobufagin; Helle, hellebrigenin.
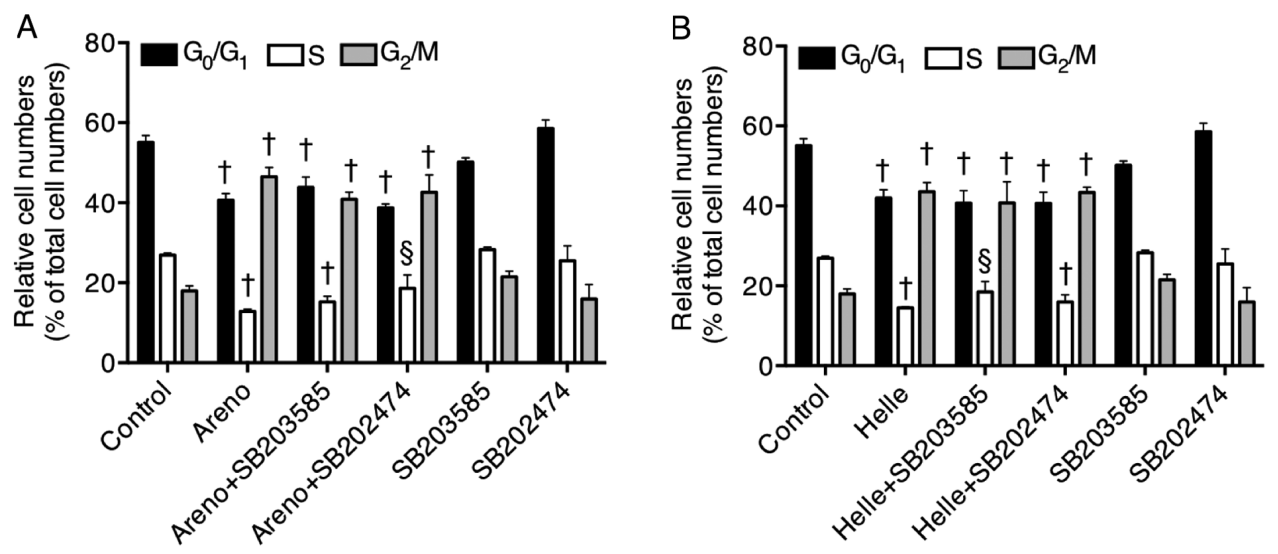

Figure 11. Effect of a p38 inhibitor on the G2/M phase arrest induced by Areno and Helle in U-87 cells. Following treatment with $20 \mathrm{ng} / \mathrm{ml}$ of (A) Areno and (B) Helle, in the presence or absence of $1 \mu \mathrm{M}$ SB203580, a specific inhibitor of p38 MAPK and its negative control SB202474 for $48 \mathrm{~h}$, cell cycle analysis was performed using a FACSCanto flow cytometer as described in Materials and methods. Data are presented as the mean \pm standard deviation from three independent experiments. ${ }^{\S} \mathrm{P}<0.001$ and ${ }^{\dagger} \mathrm{P}<0.0001$ vs. respective control. Areno, arenobufagin; Helle, hellebrigenin.

It was further demonstrated that necrotic cell death was observed in U-87 cells when treated with a relatively high concentration $(>100 \mathrm{ng} / \mathrm{ml})$, but not a relatively low concentration $(<40 \mathrm{ng} / \mathrm{ml})$ of each drug as evidence by the LDH leakage assay. However, apoptotic DNA fragmentation was not observed in the cells regardless of drug concentrations used, although arenobufagin and hellebrigenin have been reported to induce apoptosis in human hepatocellular carcinoma cells $(16,45)$, suggesting whether induction of apoptosis by arenobufagin or hellebrigenin may be cell-specific. Collectively, rather than apoptosis induction, cell cycle arrest and necrotic cell death are more likely to contribute the cytotoxicity induced by a relatively low and high concentration of each drug.

Increasing evidence has indicated an important role for the PI3K/Akt signaling pathway in the regulation of cell survival and death in response to diverse stimuli, including the majority 
of chemotherapeutic agents $(46,47)$. In addition, members of the MAPK family, consisting of p38, Erk and JNK, are also involved in a range of cellular functions, including proliferation, cell cycle arrest and cell death $(26,27,48,49)$. In the present study, evident activation of p38 MAPK pathway was observed in U-87 cells when treated with arenobufagin or hellebrigenin as evidenced by a marked increase in the expression levels of phospho-p38 and its direct downstream target, phospho-MK2 (25). In comparison to the expression pattern of phospho-p38, only a modest increase in the expression level of phospho-Akt and phospho-Erk was observed in the treated cells, and no expression of phospho-JNK was detected regardless of treatment with the two drugs. These results thus suggest that the cytotoxicities of arenobufagin and hellebrigenin are primarily associated with p38 MAPK, rather than Akt, Erk and JNK, and led to the exploration of the possible functional interactions between the activation of the p38 MAPK pathway and the cytotoxicities of the two drugs. It was surprising that a specific inhibitor of p38 MAPK per se caused a significant decrease in the cell viability, and enhanced the cytotoxicity of arenobufagin or hellebrigenin as evidenced by the XTT assays, suggesting that p38 MAPK serves an important pro-survival role in the cells. In agreement with these findings, previous studies have demonstrated a pro-survival role for $\mathrm{p} 38$ MAPK in different types of cells, including human glioblastoma cells $(48,50)$. Sooman et al $(27)$ reported that p38 MAPK phosphorylation may be a prognostic marker for patients with high-grade glioma, and vandetanib combined with a 38 MAPK inhibitor may be a useful combination chemotherapy for patients with glioma. Considering the results of previous studies and the observations in the present study, we hypothesized that combining a p38 MAPK inhibitor with arenobufagin or hellebrigenin may improve the efficacy of both drugs, and may provide more therapeutic benefits to patients with glioblastoma, although the precise contribution of the $\mathrm{p} 38$ MAPK pathway to the cytotoxicity of the two drugs warrants further investigation in a glioblastoma xenograft model. Although the activation of p38 MAPK has been associated with cell cycle arrest, apoptotic and necrotic cell death in other cancer cells, including HL-60, a human promyelocytic cell line and MCF-7 $(21,26)$, no alteration in $\mathrm{G}_{2} / \mathrm{M}$ cell cycle arrest, LDH leakage or DNA fragmentation was observed in U-87 cells treated with the two drugs combined with a specific inhibitor of p38 MAPK when compared with treatment with each drug alone. This suggests that these cellular responses are independent of the activation of the p38 MAPK pathway. These findings are supported by a previous study, which revealed that $\mathrm{p} 38$ MAPK promotes cell survival in response to DNA damage, but is not required for the $\mathrm{G}_{2}$ DNA damage checkpoint in human cancer cells, including HeLa and A549, a human lung cancer cell line (25).

A report revealed that U87 cells are not the original glioblastoma cell line that was established in 1968 at the University of Uppsala (51). The authors of the report demonstrated that the cell line is of central nervous system origin and is likely to be a bona fide human glioblastoma cell line, with an unknown patient origin. Marampon et al (52) demonstrated that histone deacetylase (HDAC) 4 and 6 expression is significantly associated with negative prognostic factors in patients with glioblastoma multiforme, treated with temozolomide and radiotherapy. They hypothesized that HDAC4 and/or HDAC6 knockdown may lead to chromatin decondensation, favoring DNA damage. By using U87 cells stably transfected with HDAC4 or HDAC6 short hairpin RNA, it was demonstrated that these two HDACs differentially regulated the molecular mechanisms responsible for DNA double-strand break repair, by protecting glioblastoma multiforme cells from cell death mediated by radiotherapy-induced senescence, apoptosis or autophagy (52). These results demonstrate that scientific findings observed in the clinical samples of patients with glioblastoma multiforme may be successfully verified in the U87 cells line despite the aforementioned misidentification issue, suggesting the outcomes of the current study are appropriate for the evaluation of the effects of arenobufagin and hellebrigenin.

The present study demonstrated that arenobufagin and hellebrigenin exhibited distinct cytotoxicity against cancerous glial cells with high potency, selectivity and tolerability, and further demonstrated that the inhibition of cell proliferation and colony formation, $\mathrm{G}_{2} / \mathrm{M}$ cell cycle arrest as well as necrotic cell death were attributed to their toxicities. Considering the important role of survivin in diverse cellular responses in various types of cancer cells, including glioblastoma $(19,42,43)$, the cytotoxicity of both drugs against cancer cells may be primarily attributed to the downregulation of survivin expression. The efforts to evaluate the mechanisms underlying functional interactions between survivin and cellular responses, including cell cycle arrest and necrotic cell death, in the treated U-87 cells in our laboratory are ongoing. Given that p38 MAPK serves an essential role in promoting glioblastoma cell survival $(27,50)$, and as an optimal chemotherapeutic regimen for glioblastoma has not been defined at present $(53,54)$, developing a combination regimen of arenobufagin/hellebrigenin plus a p38 MAPK inhibitor with the aim of preventing the activation of the p38 MAPK pathway may provide novel insight into approaches designed to treat glioblastoma. To the best of our knowledge, the results of the present study demonstrated, for the first time, the existence of arenobufagin in cerebrospinal fluid of rats who received a single oral dose of the drug, supporting the clinical application of arenobufagin and/or hellebrigenin for patients with glioblastoma.

\section{Acknowledgements}

Not applicable.

\section{Funding}

This study was supported in part by grants from the National Standardization Project of Chinese Medicine (grant no. ZYBZH-C-AH-01).

\section{Availability of data and materials}

All data generated or analyzed during this study are included in this published article.

\section{Authors' contributions}

LH and BY contributed equally to this study; LH, RS and BY performed experiments; BY and LH analyzed results and 
presented; HH, NS, HZ, BB and NT assisted interpretation of the result with BY; BY designed the research and wrote the manuscript. All authors read and approved the final manuscript.

\section{Ethics approval and consent to participate}

The experimental procedures complied with the Animal Ethics Committee Guidelines of Beijing Animals Science Biology Technology Co., Ltd. (Beijing, China; registration no. 170703002) and was approved by the Committee of Animal Care and Welfare of Tokyo University of Pharmacy and Life Sciences (Tokyo, Japan; registration no. P17-60).

\section{Patient consent for publication}

Not applicable.

\section{Competing interests}

The authors declare that they have no competing interests.

\section{References}

1. Furnari FB, Fenton T, Bachoo RM, Mukasa A, Stommel JM, Stegh A, Hahn WC, Ligon KL, Louis DN, Brennan C, et al: Malignant astrocytic glioma: Genetics, biology, and paths to treatment. Genes Dev 21: 2683-2710, 2007.

2. Stupp R, Tonn JC, Brada M and Pentheroudakis G; ESMO Guidelines Working Group: High-grade malignant glioma: ESMO Clinical Practice Guidelines for diagnosis, treatment and follow-up. Ann Oncol 21 (Suppl 5): v190-v193, 2010.

3. Sathornsumetee S, Reardon DA, Desjardins A, Quinn JA, Vredenburgh JJ and Rich JN: Molecularly targeted therapy for malignant glioma. Cancer 110: 13-24, 2007.

4. Wen PY and Kesari S: Malignant gliomas in adults. N Engl J Med 359: 492-507, 2008.

5. Stupp R, Mason WP, van den Bent MJ, Weller M, Fisher B, Taphoorn MJ, Belanger K, Brandes AA, Marosi C, Bogdahn U, et al; European Organisation for Research and Treatment of Cancer Brain Tumor and Radiotherapy Groups; National Cancer Institute of Canada Clinical Trials Group: Radiotherapy plus concomitant and adjuvant temozolomide for glioblastoma. N Engl J Med 352: 987-996, 2005.

6. Chen Z, Zhai XF, Su YH, Wan XY, Li J, Xie JM and Gao B: Clinical observation of cinobufacini injection used to treat moderate and advanced primary liver cancer. Zhong Xi Yi Jie He Xue Bao 1: 184-186, 2003 (In Chinese).

7. Qin TJ, Zhao XH, Yun J, Zhang LX, Ruan ZP and Pan BR: Efficacy and safety of gemcitabine-oxaliplatin combined with huachansu in patients with advanced gallbladder carcinoma. World J Gastroenterol 14: 5210-5216, 2008.

8. Meng Z, Yang P, Shen Y, Bei W, Zhang Y, Ge Y, Newman RA, Cohen L, Liu L, Thornton B, et al: Pilot study of huachansu in patients with hepatocellular carcinoma, nonsmall-cell lung cancer, or pancreatic cancer. Cancer 115: 5309-5318, 2009.

9. Yuan B, He J, Kisoh K, Hayashi H, Tanaka S, Si N, Zhao HY, Hirano T, Bian B and Takagi N: Effects of active bufadienolide compounds on human cancer cells and $\mathrm{CD} 4^{+} \mathrm{CD} 25^{+} \mathrm{Foxp} 3^{+}$ regulatory $\mathrm{T}$ cells in mitogen-activated human peripheral blood mononuclear cells. Oncol Rep 36: 1377-1384, 2016.

10. Facciabene A, Motz GT and Coukos G: T-regulatory cells: Key players in tumor immune escape and angiogenesis. Cancer Res 72: 2162-2171, 2012.

11. Maruyama T, Kono K, Mizukami Y, Kawaguchi Y, Mimura K, Watanabe M, Izawa S and Fujii H: Distribution of Th17 cells and FoxP3(+) regulatory $\mathrm{T}$ cells in tumor-infiltrating lymphocytes, tumor-draining lymph nodes and peripheral blood lymphocytes in patients with gastric cancer. Cancer Sci 101: 1947-1954, 2010.

12. Sakaguchi S: Naturally arising Foxp3-expressing CD $25^{+} \mathrm{CD} 4^{+}$ regulatory $\mathrm{T}$ cells in immunological tolerance to self and non-self. Nat Immunol 6: 345-352, 2005.
13. Kon A, Yuan B, Hanazawa T, Kikuchi H, Sato M, Furutani R, Takagi $\mathrm{N}$ and Toyoda $\mathrm{H}$ : Contribution of membrane progesterone receptor $\alpha$ to the induction of progesterone-mediated apoptosis associated with mitochondrial membrane disruption and caspase cascade activation in Jurkat cell lines. Oncol Rep 30: 1965-1970, 2013.

14. Yao M, Yuan B, Wang X, Sato A, Sakuma K, Kaneko K, Komuro H, Okazaki A, Hayashi H, Toyoda H, et al: Synergistic cytotoxic effects of arsenite and tetrandrine in human breast cancer cell line MCF-7. Int J Oncol 51: 587-598, 2017.

15. Yuan B, Okusumi S, Yoshino Y, Moriyama C, Tanaka S, Hirano T, Takagi N and Toyoda H: Delphinidin induces cytotoxicity and potentiates cytocidal effect in combination with arsenite in an acute promyelocytic leukemia NB4 cell line. Oncol Rep 34: 431-438, 2015.

16. Deng LJ, Hu LP, Peng QL, Yang XL, Bai LL, Yiu A, Li Y, Tian HY, Ye WC and Zhang DM: Hellebrigenin induces cell cycle arrest and apoptosis in human hepatocellular carcinoma HepG2 cells through inhibition of Akt. Chem Biol Interact 219: 184-194, 2014.

17. Deng LJ, Peng QL, Wang LH, Xu J, Liu JS, Li YJ, Zhuo ZJ, Bai LL, Hu LP, Chen WM, et al: Arenobufagin intercalates with DNA leading to G2 cell cycle arrest via ATM/ATR pathway. Oncotarget 6: 34258-34275, 2015.

18. Hsu CM, Tsai Y, Wan L and Tsai FJ: Bufalin induces G2/M phase arrest and triggers autophagy via the TNF, JNK, BECN-1 and ATG8 pathway in human hepatoma cells. Int J Oncol 43: 338-348, 2013.

19. Chakravarti A, Zhai GG, Zhang M, Malhotra R, Latham DE, Delaney MA, Robe P, Nestler U, Song Q and Loeffler J: Survivin enhances radiation resistance in primary human glioblastoma cells via caspase-independent mechanisms. Oncogene 23: 7494-7506, 2004.

20. Cargnello $M$ and Roux PP: Activation and function of the MAPKs and their substrates, the MAPK-activated protein kinases. Microbiol Mol Biol Rev 75: 50-83, 2011

21. Kikuchi H, Yuan B, Yuhara E, Takagi N and Toyoda H: Involvement of histone $\mathrm{H} 3$ phosphorylation through p38 MAPK pathway activation in casticin-induced cytocidal effects against the human promyelocytic cell line HL-60. Int J Oncol 43: 2046-2056, 2013.

22. Yao J, Qian CJ, YeB,Zhang X and Liang Y: ERK inhibition enhances TSA-induced gastric cancer cell apoptosis via NF- $\kappa \mathrm{B}$-dependent and Notch-independent mechanism. Life Sci 91: 186-193, 2012.

23. Kikuchi H, Yuan B, Yuhara E, Imai M, Furutani R, Fukushima S, Hazama S, Hirobe C, Ohyama K, Takagi N, et al: Involvement of histone $\mathrm{H} 3$ phosphorylation via the activation of p38 MAPK pathway and intracellular redox status in cytotoxicity of HL-60 cells induced by Vitex agnus-castus fruit extract. Int J Oncol 45: 843-852, 2014.

24. Zanotto-Filho A, Braganhol E, Battastini AM and Moreira JC: Proteasome inhibitor MG132 induces selective apoptosis in glioblastoma cells through inhibition of PI3K/Akt and NFkappaB pathways, mitochondrial dysfunction, and activation of p38-JNK1/2 signaling. Invest New Drugs 30: 2252-2262, 2012.

25. Phong MS, Van Horn RD, Li S, Tucker-Kellogg G, Surana U and Ye XS: p38 mitogen-activated protein kinase promotes cell survival in response to DNA damage but is not required for the G(2) DNA damage checkpoint in human cancer cells. Mol Cell Biol 30: 3816-3826, 2010.

26. Pereira L,Igea A, Canovas B, Dolado I and Nebreda AR: Inhibition of p38 MAPK sensitizes tumour cells to cisplatin-induced apoptosis mediated by reactive oxygen species and JNK. EMBO Mol Med 5: 1759-1774, 2013.

27. Sooman L, Lennartsson J, Gullbo J, Bergqvist M, Tsakonas G, Johansson F, Edqvist PH, Pontén F, Jaiswal A, Navani S, et al: Vandetanib combined with a p38 MAPK inhibitor synergistically reduces glioblastoma cell survival. Med Oncol 30: 638, 2013.

28. Van Heerden FR and Vleggaar R: A revised 13C NMR spectral assignment of hellebrigenin. Magn Reson Chem 26: 464-467, 1988.

29. Hayashi H, Campenot RB, Vance DE and Vance JE: Glial lipoproteins stimulate axon growth of central nervous system neurons in compartmented cultures. J Biol Chem 279: 14009-14015, 2004.

30. Cao YD, Zhang LZ, Wang MS, Tang TY and Su WH: Two methods to collect cerebrospinal fluid in SD rat. Acta Acad Med XuZhou 25: 317-319, 2005.

31. Yoshino Y, Yuan B, Kaise T, Takeichi M, Tanaka S, Hirano T, Kroetz DL and Toyoda H: Contribution of aquaporin 9 and multidrug resistance-associated protein 2 to differential sensitivity to arsenite between primary cultured chorion and amnion cells prepared from human fetal membranes. Toxicol Appl Pharmacol 257: 198-208, 2011. 
32. Yuan B, Ohyama K, Bessho T, Uchide N and Toyoda H: Imbalance between ROS production and elimination results in apoptosis induction in primary smooth chorion trophoblast cells prepared from human fetal membrane tissues. Life Sci 82: 623-630, 2008.

33. Cesarone CF, Bolognesi C and Santi L: Improved microfluorometric DNA determination in biological material using 33258 Hoechst. Anal Biochem 100: 188-197, 1979.

34. Kreuter J: Nanoparticulate systems for brain delivery of drugs. Adv Drug Deliv Rev 47: 65-81, 2001.

35. Li F, Weng Y, Wang L, He H, Yang J and Tang X: The efficacy and safety of bufadienolides-loaded nanostructured lipid carriers. Int J Pharm 393: 203-211, 2010.

36. Yu CL and Hou HM: Plasma pharmacokinetics and tissue distribution of bufotalin in mice following single-bolus injection and constant-rate infusion of bufotalin solution. Eur J Drug Metab Pharmacokinet 35: 115-121, 2011.

37. Gavet $\mathrm{O}$ and Pines J: Progressive activation of CyclinB1-Cdk1 coordinates entry to mitosis. Dev Cell 18: 533-543, 2010.

38. Perdiguero E and Nebreda AR: Regulation of Cdc25C activity during the meiotic G2/M transition. Cell Cycle 3: 733-737, 2004

39. Zhao S, Tsuchida T, Kawakami K, Shi C and Kawamoto K: Effect of As2O3 on cell cycle progression and cyclins D1 and B1 expression in two glioblastoma cell lines differing in p53 status. Int J Oncol 21: 49-55, 2002.

40. Momeny M, Moghaddaskho F, Gortany NK, Yousefi H, Sabourinejad Z, Zarrinrad G, Mirshahvaladi S, Eyvani H, Barghi F, Ahmadinia L, et al: Blockade of vascular endothelial growth factor receptors by tivozanib has potential anti-tumour effects on human glioblastoma cells. Sci Rep 7: 44075, 2017.

41. Zhang YX, Li XF, Yuan GQ, Hu H, Song XY, Li JY, Miao XK, Zhou TX, Yang WL, Zhang XW, et al: $\beta$-Arrestin 1 has an essential role in neurokinin-1 receptor-mediated glioblastoma cell proliferation and G2/M phase transition. J Biol Chem 292: 8933-8947, 2017

42. Chen X, Duan N, Zhang C and Zhang W: Survivin and Tumorigenesis: Molecular Mechanisms and Therapeutic Strategies. J Cancer 7: 314-323, 2016.

43. Shirai K, Suzuki Y, Oka K, Noda SE, Katoh H, Suzuki Y, Itoh J, Itoh $\mathrm{H}$, Ishiuchi S, Sakurai $\mathrm{H}$, et al: Nuclear survivin expression predicts poorer prognosis in glioblastoma. J Neurooncol 91: 353-358, 2009.

44. Li Y, Liu D, Zhou Y, Li Y, Xie J, Lee RJ, Cai Y and Teng L: Silencing of survivin expression leads to reduced proliferation and cell cycle arrest in cancer cells. J Cancer 6: 1187-1194, 2015.
45. Zhang DM, Liu JS, Deng LJ, Chen MF, Yiu A, Cao HH, Tian HY, Fung KP, Kurihara H, Pan JX, et al: Arenobufagin, a natural bufadienolide from toad venom, induces apoptosis and autophagy in human hepatocellular carcinoma cells through inhibition of PI3K/Akt/mTOR pathway. Carcinogenesis 34: 1331-1342, 2013.

46. Hennessy BT, Smith DL, Ram PT, Lu Y and Mills GB: Exploiting the PI3K/AKT pathway for cancer drug discovery. Nat Rev Drug Discov 4: 988-1004, 2005.

47. Garcia-Echeverria C and Sellers WR: Drug discovery approaches targeting the PI3K/Akt pathway in cancer. Oncogene 27: 5511-5526, 2008

48. Gutiérrez-Uzquiza Á, Arechederra M, Bragado P, Aguirre-Ghiso JA and Porras A: p38 $\alpha$ mediates cell survival in response to oxidative stress via induction of antioxidant genes: Effect on the p70S6K pathway. J Biol Chem 287: 2632-2642, 2012.

49. Chen Y, Yang W, Zhang X, Yang S, Peng G, Wu T, Zhou Y, Huang C, Reinach PS, Li W, et al: MK2 inhibitor reduces alkali burn-induced inflammation in rat cornea. Sci Rep 6: 28145, 2016.

50. Yoshino Y, Aoyagi M, Tamaki M, Duan L, Morimoto T and Ohno K: Activation of p38 MAPK and/or JNK contributes to increased levels of VEGF secretion in human malignant glioma cells. Int J Oncol 29: 981-987, 2006.

51. Allen M, Bjerke M, Edlund H, Nelander S and Westermark B: Origin of the U87MG glioma cell line: Good news and bad news. Sci Transl Med 8: 354re3, 2016.

52. Marampon F, Megiorni F, Camero S, Crescioli C, McDowell HP, Sferra R, Vetuschi A, Pompili S, Ventura L, De Felice F, et al: HDAC4 and HDAC6 sustain DNA double strand break repair and stem-like phenotype by promoting radioresistance in glioblastoma cells. Cancer Lett 397: 1-11, 2017.

53. Fine HA, Dear KB, Loeffler JS, Black PM and Canellos GP: Meta-analysis of radiation therapy with and without adjuvant chemotherapy for malignant gliomas in adults. Cancer 71: 2585-2597, 1993.

54. Stewart LA: Chemotherapy in adult high-grade glioma: A systematic review and meta-analysis of individual patient data from 12 randomised trials. Lancet 359: 1011-1018, 2002.

This work is licensed under a Creative Commons Attribution-NonCommercial-NoDerivatives 4.0 International (CC BY-NC-ND 4.0) License. 